\title{
Effect of gastric juice on iron absorption in patients with gastric atrophy
}

\author{
A. JACOBS AND G. M. OWEN \\ From the Welsh National School of Medicine and Velindre Hospital, Cardiff
}

The influence of gastric juice on iron absorption has been studied extensively in recent years. The absorption of haemoglobin iron is unaffected by achlorhydria (Biggs, Bannerman, and Callender, 1962) but inorganic iron is better absorbed in the presence of normal gastric juice (Goldberg, Lochhead, and Dagg, 1963; Cook, Brown, and Valberg, 1964). It has been shown that the administration of hydrochloric acid to patients with achlorhydria will increase iron absorption (Jacobs, Bothwell, and Charlton, 1964) but it has also been suggested that other gastric juice constituents also play a part. Koepke and Stewart (1964) and Murray and Stein (1967) have produced evidence from experiments in dogs and rats that the stomach secretes an absorptionpromoting factor which is increased in some conditions associated with high iron absorption. Davis, Luke, and Deller (1966), on the other hand, demonstrated an iron-binding protein in normal gastric juice which was absent in patients with high iron absorption. They suggested that this substance, which they call gastroferrin, inhibits inorganic iron absorption and that variations in its secretion provide a physiological mechanism for regulating the uptake of iron from the body.

The object of the present study was to see whether normal human gastric juice influences the absorption of inorganic iron in human subjects with gastric atrophy when given together with a standard meal under conditions in which gastric $p \mathrm{H}$ is maintained at neutrality. Clear evidence was produced that gastric juice promotes iron absorption even when the local effect of acid is eliminated. No inhibitory effect was observed.

\section{METHODS}

SUBJECTS WITH GASTRIC ATROPHY Sixteen patients with fully treated pernicious anaemia volunteered to have three successive iron absorption tests. They were all haematologically normal at the time of the tests and were taking no haematinics other than regular injections of vitamin $B_{12}$. Haemoglobin concentration in this group was in the range 13.5 to $17 \cdot 1 \mathrm{~g}$ per $100 \mathrm{ml}$. All patients had been shown to have a histamine-fast achlorhydria.
IRON ABSORPTION TESTS Iron was administered as ${ }^{59} \mathrm{Fe}$ labelled ferric citrate (RCC IFS 2P) with an activity of $5 \mu \mathrm{Ci}$ added to a standard meal consisting of $200 \mathrm{ml}$ tinned cream of chicken soup with $2 \mathrm{oz}$ of minced breast of chicken. The total iron content of each meal was $4.2 \mathrm{mg}$, most of this being derived from the soup and only a few micrograms being added with the radioactive isotope. The soup was heated to $40^{\circ} \mathrm{C}$ before administration in all cases. All the test meals were given in the morning after an overnight fast and nothing was taken by mouth for the following two hours. This particular test meal had a number of advantages over those consisting of more solid items. A constant composition in terms of protein, carbohydrate, and iron content thoughout the tests was easy to ensure and mixing and incubation with gastric juice before administration was more efficient. Iron absorption was measured by whole body counting using a modified scintiscanner and a profile integration technique (Owen, Kirkman, Williams, and Jacobs, 1967). The $100 \%$ activity was measured three to four hours after the oral dose was given and retention was measured after 14 days. The second and third doses of radioactive iron were given at 14 and 28 days after the first dose and after absorption from the preceding doses had been measured. All the patients were given the first dose of iron after the soup had been mixed with $200 \mathrm{ml}$ water. The freshly stimulated gastric juice used in subsequent tests was obtained during histamine infusions in normal subjects or patients with duodenal ulcer and was free of blood and bile. Fifteen patients received a second dose in which iron-containing chicken soup was mixed with $200 \mathrm{ml}$ fresh, neutralized gastric juice before administration. For the third dose 13 patients were given $200 \mathrm{ml}$ of ironcontaining soup which had been incubated with $200 \mathrm{ml}$ fresh acid gastric juice for one hour at $37^{\circ} \mathrm{C}$ before neutralization with $12.5 \mathrm{M} \mathrm{NaOH}$ solution. Three patients who did not have the third test were given $200 \mathrm{ml}$ soup mixed with $200 \mathrm{ml}$ fresh acid juice. The buffering capacity of the soup was such that the $p \mathrm{H}$ on administration was 3 to 4 . In all the other tests the $p \mathrm{H}$ of the meal on administration was 6 to 8 .

\section{RESULTS}

Iron absorption expressed as a percentage of the radioactivity given in each case is shown in Fig. 1, and the mean value in each group is shown in Table I. The iron absorption in individual tests is 


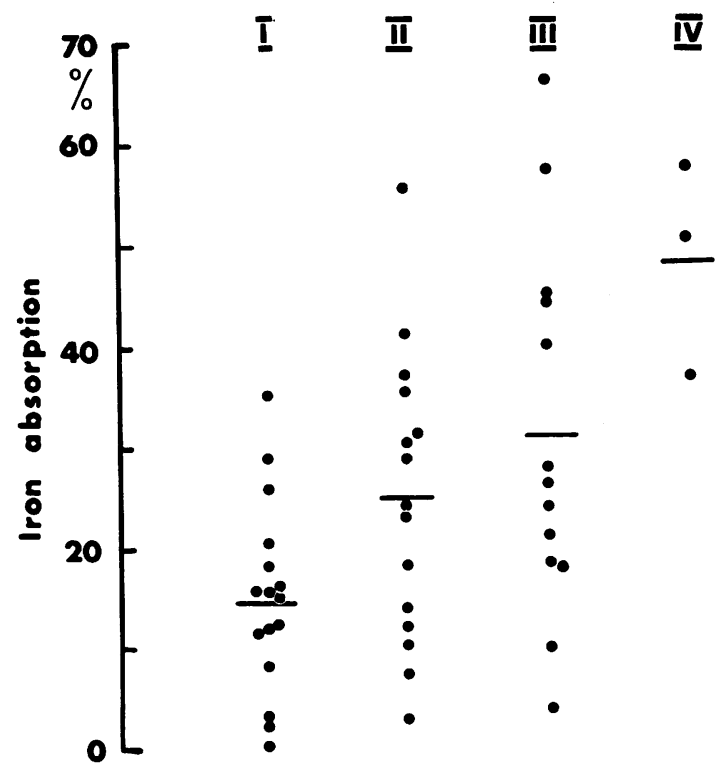

FIG. 1. Iron absorption in patients with gastric atrophy showing the effect of $I, 200 \mathrm{ml}$ water; $11,200 \mathrm{ml}$ neutralized gastric juice, III, $200 \mathrm{ml}$ acid gastric juice incubated with the test meal for one hour before neutralization; and IV, $200 \mathrm{ml}$ acid gastric juice.

TABLE I

IRON ABSORPTION IN PATIENTS WITH GASTRIC ATROPHY

\begin{tabular}{|c|c|c|c|}
\hline \multicolumn{2}{|c|}{ Test Meal } & \multirow{2}{*}{$\begin{array}{l}\begin{array}{l}\text { Number } \\
\text { of } \\
\text { Patients }\end{array} \\
16\end{array}$} & \multirow{2}{*}{$\begin{array}{l}\begin{array}{l}\text { Mean Absorption }{ }^{1} \\
( \pm \mathrm{SE})\end{array} \\
14 \cdot 5 \pm 2 \cdot 18\end{array}$} \\
\hline I & Soup $+200 \mathrm{ml}$ water & & \\
\hline II & $\begin{array}{l}\text { Soup }+200 \mathrm{ml} \text { neutralized } \\
\text { gastric juice }\end{array}$ & 15 & $24 \cdot 6 \pm 3 \cdot 72^{2}$ \\
\hline III & $\begin{array}{l}\text { Soup incubated with } 200 \mathrm{ml} \\
\text { acid juice before neutralization }\end{array}$ & 13 & $30 \cdot 9 \pm 5 \cdot 18^{3}$ \\
\hline IV & Soup $+200 \mathrm{ml}$ acid juice & 3 & $48 \cdot 2 \pm 14 \cdot 28$ \\
\hline
\end{tabular}

'Percentages.

Significance of difference from I

${ }^{2} \mathbf{P}<0.05$.

${ }^{3} \mathbf{P}<0.01$.

shown in Table II. In 15 subjects paired observations are available for basic absorption (I) and absorption with neutralized gastric juice (II). Evaluation of the differences shows them to be highly significant $(t=3.65, P<0.005)$. In 13 subjects the difference between basic absorption (I) and absorption after preincubation with gastric juice (III) shows a similar degree of significance $(t=4 \cdot 29, P<0.005)$. The addition of neutralized gastric juice to the test meal thus results in an increase in absorption and there is an even greater increase when the meal is incubated with acid gastric juice before neutralization. This effect could not be due to changes in the gastric $p H$ or that of the meal at the time of administration. In
TABLE II

IRON ABSORPTION IN INDIVIDUAL PATIENTS USING DIFFERENT TEST PROCEDURES ${ }^{1}$

\begin{tabular}{|c|c|c|c|c|}
\hline \multirow[t]{2}{*}{ Subject } & \multicolumn{4}{|c|}{ Type of Test ${ }^{2}$} \\
\hline & $I$ & II & III & $I V$ \\
\hline 1 & $11 \cdot 7$ & $30 \cdot 2$ & - & $36 \cdot 7$ \\
\hline 2 & $15 \cdot 3$ & 30.9 & 一 & $57 \cdot 5$ \\
\hline 3 & $11 \cdot 1$ & $13 \cdot 7$ & - & $50 \cdot 4$ \\
\hline 4 & $25 \cdot 4$ & $23 \cdot 8$ & $65 \cdot 7$ & - \\
\hline 5 & 34.9 & $41 \cdot 1$ & $40 \cdot 2$ & - \\
\hline 6 & $28 \cdot 7$ & $28 \cdot 7$ & $57 \cdot 2$ & - \\
\hline 7 & $20 \cdot 3$ & $55 \cdot 4$ & $45 \cdot 0$ & - \\
\hline 8 & $15 \cdot 4$ & 35.4 & $18 \cdot 3$ & - \\
\hline 9 & $15 \cdot 0$ & $37 \cdot 0$ & $44 \cdot 0$ & 一 \\
\hline 10 & $11 \cdot 0$ & $12 \cdot 0$ & $4 \cdot 0$ & - \\
\hline 11 & $3 \cdot 0$ & $7 \cdot 0$ & $10 \cdot 0$ & - \\
\hline 12 & Nil & $18 \cdot 0$ & $26 \cdot 0$ & - \\
\hline 13 & $2 \cdot 0$ & $10 \cdot 0$ & $18 \cdot 0$ & 一 \\
\hline 14 & $12 \cdot 0$ & $23 \cdot 0$ & $28 \cdot 0$ & - \\
\hline 15 & $8 \cdot 0$ & $3 \cdot 0$ & $24 \cdot 0$ & - \\
\hline 16 & $18 \cdot 0$ & - & $21 \cdot 0$ & - \\
\hline
\end{tabular}

1Percentages.

${ }^{2}$ Tests as in Table I.

the three cases in which the meal was given with unneutralized gastric juice, absorption was considerably increased.

\section{DISCUSSION}

In iron-deficiency anaemia impaired iron absorption is found in those subjects with gastric atrophy (Goldberg et al, 1963; Jacobs, Lawrie, Entwistle, and Campbell, 1966a). A similar impairment is found in anaemic rats after gastrectomy (Rieber, Conrad, and Crosby, 1967) and this is due to loss of a factor in the gastric secretion (Murray and Stein, 1967). The effect of gastric juice appears to be at least partly due to the presence of hydrochloric acid (Jacobs et al, 1964) and the effect of administration of acid gastric juice in the three subjects in group IV confirms the effect observed by Cook et al (1964).

Results of the other tests show that this is not the only factor involved. The test meals were all administered at neutral $p \mathrm{H}$ and the presence of complete achlorhydria in the recipients indicates that gastric juice can promote iron absorption irrespective of the $p \mathrm{H}$ in the gastrointestinal lumen. A similar study on five patients by Cook et al (1964), using neutralized gastric juice and a test meal consisting of bread, gave inconclusive results. Studies in vitro have shown that gastric juice contains substances that combine with iron at low $p \mathrm{H}$ to form complexes that remain soluble after neutralization and that this maintains iron in a form suitable for absorption (Jacobs and Miles, 1968). If the increase in iron absorption produced by neutral gastric juice is due to the formation of such complexes then the greater effect of preincubating the juice at acid $p \mathrm{H}$ before neutralization might be 
due to the increased complexing known to occur in vitro under these conditions. In addition the peptic digestion of protein is likely to provide additional ligands for complex formation, an effect which would not be apparent if the test meal contained no protein.

Koepke and Stewart (1964) found a substance in the gastric juice of anaemic dogs that stimulated iron absorption in normal dogs. Murray and Stein (1968) have claimed a similar effect for gastric juice from iron-deficient and haemochromatotic patients on iron absorption in rats. They suggest that the gastric mucosa responds to iron deficiency by an increased secretion of the absorption-promoting factor and that this is a physiological mechanism for the regulation of iron absorption. Similar experiments using iron-deficient patients as donors of gastric juice and normal human volunteers as recipients showed no stimulation of iron absorption by 'anaemic' gastric juice (Jacobs, Rhodes, and Eakins, 1967). It seems unlikely that the irondeficient gastric mucosa will increase its secretion of this specific factor when it is known that acid, pepsin, and intrinsic factor secretion are all reduced in these circumstances (Jacobs, Rhodes, Peters, Campbell, and Eakins, 1966b; Stone, 1968). Our results do not support the suggestion (Davis et al, 1966; Luke, Davis, and Deller, 1967) that normal gastric juice contains an inhibitor of iron absorption.

\section{SUMMARY}

When inorganic iron is given to patients with complete achlorhydria absorption is increased by the simultaneous administration of neutralized normal gastric juice. Gastric juice potentiates iron absorption even when the effect of acid is eliminated.

\section{REFERENCES}

Biggs, J. C., Bannerman, R. M., and Callender, S. T. (1962). Iron absorption in achlorhydria. Proc. 8th Congr. europ. Soc. Haemat., 1961, pt. 1, no. 236.

Cook, J. D., Brown, G. M., and Valberg, L. S. (1964). The effect of achylia gastrica on iron absorption. J. clin. Invest., 43, 11851191.

Davis, 1. S., Luke, C. G., and Deller, D. J. (1966). Reduction of gastric iron-binding protein in haemochromatosis. Lancet, 2, 1431-1433.

Goldberg, A., Lochhead, A. C., and Dagg, J. H. (1963). Histaminefast achlorhydria and iron absorption. Ibid., 1, 848-850.

Jacobs, A., Lawrie, J. H., Entwistle, C. C., and Campbell, H. (1966a). Gastric acid secretion in chronic iron-deficiency anaemia. lbid., 2, 191-192.

- and Miles, P. (1969). The role of gastric secretion in iron absorption. Gut, in the press.

-, Rhodes, J., Peters, D. K., Campbell, H., and Eakins, J. D. (1966b). Gastric acidity and iron absorption. Brit. J. Haemat. 12, 728-736.

,-- , and Eakins, J. D. (1967). Gastric factors influencing iron absorption in anaemic patients. Scand. J. Haemat., 4, 105-110.

Jacobs, P., Bothwell, T., and Charlton, R. W. (1964). Role of hydrochloric acid in iron absorption. J. appl. Physiol., 19, 187-188.

Koepke, J. A., and Stewart, W. B. (1964). Role of gastric secretion in iron absorption. Proc. Soc. exp. Biol. (N.Y.), 115, 927-929.

Luke, C. G., Davis, P. S., and Deller, D. J. (1967). Change in gastric iron-binding protein (gastroferrin) during iron deficiency anaemia. Lancet, 2, 926-927.

Murray, M. J., and Stein, N. (1967). The integrity of the stomach as a requirement for maximal iron absorption. J. Lab. clin. Med., 70, 673-677.

$\longrightarrow$, and - (1968). A gastric factor promoting iron absorption. Lancet, 1, 614-616.

Owen, G. M., Kirkman S., Williams M., and Jacobs A. (1967). A simple method for measuring iron absorption using a scintiscanner for whole body counting. Brit. J. Radiol., 40, 866-868.

Rieber, E. E., Conrad, M. E., and Crosby, W. H. (1967). Gastrectomy and iron absorption: effects of bleeding, iron loading and ascorbic acid in rats. Proc. Soc. Exp. Biol. (N.Y.), 124, 577-580.

Stone, W. D. (1968). Gastric secretory response to iron therapy. Gut, 9, 99-105. 